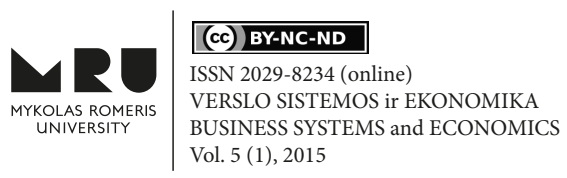

\title{
LIMITATIONS TO ASSESS THE IMPACT OF RURAL DEVELOPMENT POLICY IN THE PUGLIA REGION: THE CASE OF MEASURE 121 - AXES I
}

\author{
Pasquale PAZIENZA \\ University of Foggia, Department of Economics \\ L.go Papa Giovanni Paolo II n. 1, 71121 Foggia, Italy \\ Email: pasquale.pazienza@unifg.it \\ Donatello CARUSO \\ University of Foggia, Department of Economics \\ L.go Papa Giovanni Paolo II n. 1, 71121 Foggia, Italy \\ Email: donatello.caruso@unifg.it \\ Vincenzo VECCHIONE \\ University of Foggia, Department of Economics \\ L.go Papa Giovanni Paolo II n. 1, 71121 Foggia, Italy \\ Email: vincenzo.vecchione@unifg.it
}

doi:10.13165/VSE-15-5-1-01

\begin{abstract}
In this work, some specific aspects of the Rural Development Plan of the Puglia Region (in Southern Italy) for the period 2007-2013 are analyzed and the limitations characterizing the possibility of building an analysis framework aimed at understanding how it actually affects the regional agricultural system are highlighted. More specifically, by referring to a specific measure of the rural development program (Measure 121 of Axes I), the aim is to verify whether the investment activity implemented has actually generated some positive results which can induce us to say that the EU budget devoted to rural development is well spent. In order to achieve this purpose, the authors of the present work have worked at gathering all the information available at the Puglia Region Authority. Nevertheless, this is not helpful for the type of the analysis the authors would like to conduct. The observation of the gathered data, in fact, makes the authors observe the existence of severe limitations deriving from the way in which the Regional Authority manages the data collection. The main aim of this work is to present a framework of analysis which might be used for policy evaluation purposes and to discuss what should be further required for a useful completion of the dataset with the aim of making it the subject of empirical analyses.
\end{abstract}

Keywords: local and rural development, investment appraisal, regional policy evaluation, regional development plan measures.

JEL classification: H5, H7, O18, R11. 


\section{Introduction}

The role agriculture plays in economic development processes of countries - at a macro level - and local territories - at a micro level - is an issue which has significantly characterized the debate on development since its very beginning. The analysis of the literature refers how about fifty years ago some authors already highlighted how agriculture could strategically contribute to economic development under various aspects, such as resources use, production improvements in both quantitative and qualitative terms, and foreign exchange (Johnston, et al., 1961; Kuznets, 1964). This view was in disagreement with an opposite and previously existing idea which used to stress the importance of an industry-induced development (e.g., Rosenstein-Rodan, 1943; Hirshman, 1961). In this sense, agriculture was relegated a minor role and seen as a production sector basically characterized by a very low capability of generating an adequate multiplier effect. Since then, the literature has produced a number of evidences which now make widely accepted the recognition of the positive role agriculture exerts in development processes. This dominant thinking has even more recently received support from other works. For example, authors, such as Adelman (1984), Hazell and Haggblade (1991) and Haggblade et al. (2007), have all shown that improvements in farms' productivity can also generate some trickle-down effects on non-farm activities and this is particularly true for those industries related to the agro-food sector. It has also been referred how growth in the agricultural sector can generate improvements in the economy of both countries and territorial systems (Mellor, 2000).

It is by building on these type of arguments and evidences specifically produced by the scientific literature that policy makers at various levels have always put agriculture at the center of their attention. This is even true at the European level. As it is known, one of the main tasks of the European Union (EU) is the attempt to eliminate the economic and social disparities characterizing its regions. To this aim, it operates through the so-called structural funds which are financial instruments specifically devoted to the reduction and, possibly, the elimination of those territorial disparities. Within this framework, agriculture is considered one of the core aspects. Between 2007 and 2013, the EU allocated almost 100 billion Euros to pursue its objectives in rural development (European Court of Auditors, 2013). In this operational context, the Region of Puglia developed its operational plan through which, in addition to other objectives, specific attention was paid to the strengthening of the competitiveness of the agricultural system of the region. In this sense, the regional plan identified some measures particularly devoted to the reorganization and modernization of regional farms with the aim of making them more capable of dealing with an increasing worldwide competition.

The Measure 121 (Axes I) of the Rural Development Program adopted by the Region of Puglia has the main aim of pursuing - in accordance with Art. 20(b)(i) of Council Regulation (EC) No. 1698/2005 - the modernization of agricultural holdings through grants for investments in farm machinery and equipment, such as tractors, harvesters, farm buildings, manure storage, irrigation facilities, etc. More in detail, the policy intervention within the context of this considered measure entails a co-financing mechanism on the basis of which the private capital (the risk capital) is called to cover at least $50 \%$ of the amount proposed as an investment. The remaining 50\% represents the maximum quota of the nonrepayable public grant given in support the quota of private capital. 
The implementation of such an operational approach should help to overtake the limits highlighted in the supporting documents of the planning procedure, where it was observed how the farms belonging to the regional system are characterized by a very significant productive potential which is not yet fully expressed due to the existence of high production costs, a very modest diversification of farms' production, a quality level of agricultural productions which can be the subject of further improvements, and a very modest horizontal and vertical sectorial aggregation. In Figure 1, it can be observed how at the end of 2013 the measure in question already employed about $80 \%$ of the financial resources available for the Puglia regional plan (Ottaviani, et al., 2014).

Figure 1: Progress of the expenditure on the total program (\%)

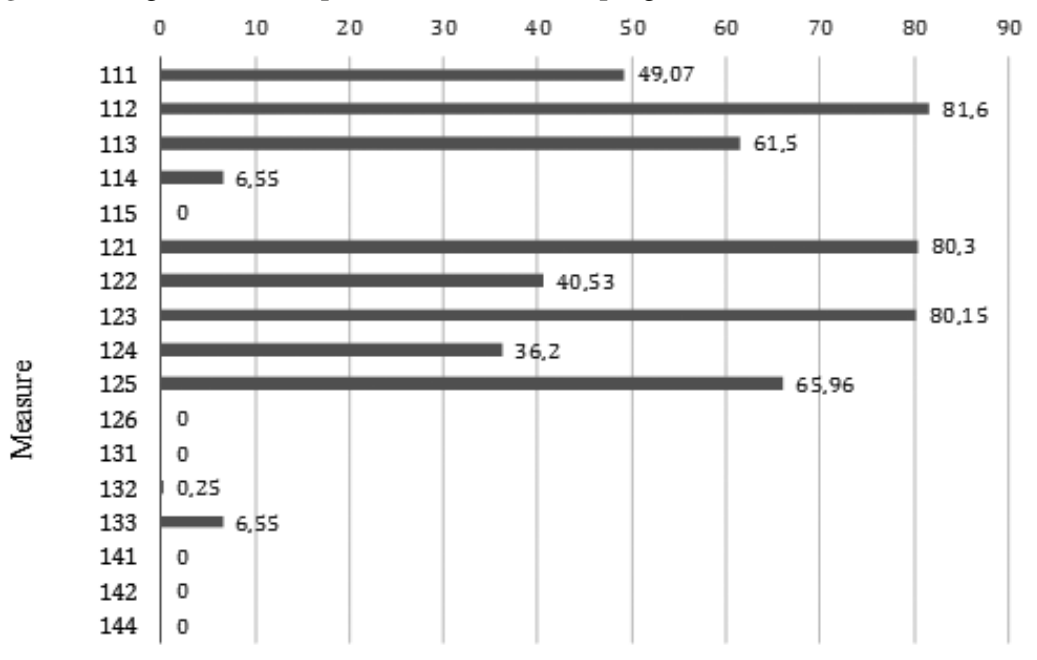

Source: Ottaviani et al. (2014)

The understanding, however, of how such a kind of policy actually impacts on the agricultural system, at a first stage, and on the regional economy, as a consequence, becomes a relevant issue. As remarked in some official reports and scientific works, in fact, the observation of whether the European expenditure for rural development produces positive results is an open question for academics and policy makers (European Court of Auditors, 2013; Bradley, et al., 2010). Authors, such as Russo (2014), Shaxon (2011), Hodge and Midmore (2008) and Russo and Sabbatini (2005), stress what has just been said and the importance of producing more precise assessments of this type of policy. In this way only, it would be possible to build a clearer view of whether and how the European policy for rural development in the various regions of its member states actually generates the expected results.

However, it must be said that over the last twenty years policy evaluation has become a prominent issue and an autonomous field of investigation. It has also occurred on the consideration of the fact that political institutions have started to pay a higher level of attention in assessing their activity with the aim of better orienting further political initiatives. This results particularly true at the European level, where it is since long time that the DG 
agriculture of the European Commission has implemented evaluation procedures and produced technical analyses aimed at pursuing what was said above and, more specifically, at observing - and eventually correcting - the way the CAP (Common Agricultural Policy) is implemented. In addition, to the end of also ensuring a more opened and participated approach, it also encourages and supports the scientific community to carry out independent analyses and studies (Esposti, et al., 2013; Lukesch, et al., 2010; EU Commission, 2006).

In agreement with Esposti and Sotte (2013), there are at least two reasons which can explain the increasing interest in policy evaluation. The first is associated with the fact that policy evolution - also in the field of agriculture - has generated certain levels of complexity in the evaluation procedures. The second can be referred to the way scientists and researchers have approached this growing complexity which has pushed them towards the identification and development of multiple and heterogeneous evaluation methods and toolboxes to adequately deal with the multiple objectives of policies (Imbens, et al., 2009).

The review of the literature makes us learn how the techniques through which policy evaluation is run can be grouped into two main areas: (1) the approaches related to the theorybased evaluation; (2) the approaches associated with the counterfactual analysis. The first type of approaches aims to understand the reasons why a policy program has, or has not, generated an actual impact through the examination of the assumption underlying the causal chain from inputs to outcomes and impacts (Weiss, 1998, 2000; White, 2009; Merlo, 2014). However, as it is often claimed, this methodological approach is unable to quantify economic benefits. For this reason, it works well only for some policy evaluation purposes, but not for all.

The latter type of approaches represents, in the field of economics, one of the basic tools for evaluating policy decisions. It assesses the impact of policies through contrasting them with alternative and hypothetical policies. According to Lankoski and Ollikainen (2013), the counterfactual analysis tries to address questions, such as "what would have happened if...?" In other terms, counterfactual analysis is actually implemented through the consideration of a non-observable case (i.e., the counterfactual case), against which policies can be evaluated. The comparison between the counterfactual and the actual case can help to understand those factors explaining the impacts of a policy. The counterfactual approach can be implemented through a series of tools, such as the difference in differences, the comparisons around the discontinuity point, the regression and regression-discontinuity analysis, the pre-post comparison, the statistical matching (Propensity Score Matching), the interrupted time-series, etc. (White, 2006; Ravallion, 2008; Gélineau, et al., 2012). Each of these tools shows strengths and weaknesses, which common factor is represented by the existence of some hypothesis which cannot be tested. The Propensity Score Matching - widely used in the literature - represents a powerful tool in those cases where it can be assumed that only those features subject of observation play a role in determining the impact of a policy action (Khandker, et al., 2010). In other terms, the robustness of this technique is limited because of the following aspects: (1) scarce possibility of making the results generally valid since they are strictly linked to the matching interval; (2) its estimates can be the subject of dangerous distortions if other variables influencing the result of the matching are present; (3) inapplicability if the amount of the non-treated cases is relevantly less than the amount of the treated cases. For these reasons, the application of the Propensity Score Matching is restricted and cannot be considered as technically valid for all those cases in which the subject of evaluation is the implementation of wide-ranging policies (Khandker, et al., 2010).

In this work, an early attempt to conceptualize a framework is made, through which 
the analysis of how the Rural Development Plan decided by the Region of Puglia for the period 2007-2013 has actually affected the regional agriculture might be possible. This particularly refers to a database received by the Puglia Region Authority. The analysis of the regional database induces us to highlight some missing aspects which make the database useless for the quantitative investigation purpose. As a result, a discussion on how the database should be reorganized and the actions the Regional Authority has to undertake to this end is required and here developed.

The work is organized as follows. A general comment on the data gathered so far is reported in the next section. In this sense, a very simple descriptive - and preliminary - analysis of the data obtained is proposed. In a further section, the model worked at to empirically assess the policy impact is introduced. In a concluding section, the limit the database received by the Puglia Region Authority is characterized and some alternatives through which some information gaps might be covered with the aim of building a database useful for the purpose of this analysis are discussed.

\section{Material and methods}

In this work, the authors conceptually approach to the identification of the impact of a policy as the quantitative modification of some specific variables (e.g., income or employment levels) in response to the implementation of policy initiatives aimed at redistributing financial resources to the end of enforcing the economic performance of considered territories. With this in mind, the authors have gathered data from the Management Authority of the Rural Development Plan of the Puglia Region which provided a database containing information at firms' level. More specifically, the database contains information on those firms which requested to be admitted to the benefits of Measure 121, Axes I of the Rural Development Plan 2007-2013 through the first public call of the 17th of May, 2012, No. 71.

The first look at the data achieved by the above mentioned Regional Authority enables us to observe how 1,321 firms out of 2,076 have actually been admitted to the benefits of the measure in question. These firms are grouped into 25 different commodity sectors from an agricultural plantation, horticulture and floriculture to livestock. For each firm, the database reports the following further information recorded at the time of the application: (a) the amount of the proposed investment; (b) public aid granted; (c) the number of family and extra-family workers; (d) revenues; (e) production costs; (f) financial amortization of firm's production goods; (g) salary and income levels before the investment implementation.

Having said this, some considerations on the way the database is organized are developed and an early analysis of the information contained in it is carried out. As it has been already said in the previous section, it must be highlighted that the database does not help us to develop an analysis of how the financial resources granted through the implementation Measure 121 has impacted the agricultural sector in the Puglia region. This is due to the fact that the information gathered by the Management Authority of the measure in question only regards the characteristics firms declare when they submit their application to participate in the public call. The database does not contain any information in relation to firms' income and/or employment levels recorded after a certain time from the implementation of the activities granted. Furthermore, the Management Authority does not run any follow-up analysis aimed at verifying how income and/or employment have performed in those firms admitted to the benefits of the public intervention. 
To overtake the severe problem represented by the lack of this type of data, which does not give us the possibility of carrying out a proper impact analysis of the policy in question, the authors have referred to another public institution of the financial administration of the Italian State (Agenzia delle entrate) to be supplied with information on income and employment levels declared in 2013 (the same will be done for 2014 and 2015) by the firms reported in the regional database. This should enable us to more properly analyze the aspect subject of our attention. More specifically, the statistical facts the authors would like to investigate in the analysis they intend to develop are schematically summarized in Table 1.

Table 1: Statistical variables subject of observation

\begin{tabular}{|l|l|l|}
\hline No & \multicolumn{1}{|c|}{ Variable } & \multicolumn{1}{c|}{ Description } \\
\hline $\mathbf{1}$ & Income & $\begin{array}{l}\text { The income of sales derived from the firm's agricultural activity as recorded } \\
\text { before the investment implementation. }\end{array}$ \\
\hline $\mathbf{2}$ & Public aid & The amount associated to the contribution granted by the regional authority. \\
\hline $\mathbf{3}$ & Risk capital & The private amount of the investment required for co-financing. \\
\hline $\mathbf{4}$ & Investment & $\begin{array}{l}\text { The total amount of the investment proposed by the firm which derives from } \\
\text { the sum between public aid and risk capital. }\end{array}$ \\
\hline $\mathbf{5}$ & Farm size & The size of the firm in ha. \\
\hline $\mathbf{6}$ & Work force & The amount of external workers, except those belonging to the farmer's family. \\
\hline
\end{tabular}

Source: own calculations

The possibility of obtaining data on the employment level and the income declared by the firms in the regional database at $t+1, t+2$ and/or $t+n$ time from the start of the program can enable us to econometrically analyse a cross-section database aiming at the estimation of the following functional form:

$$
\begin{aligned}
& y_{i t+n}=\alpha+\beta_{1} \text { Income }_{i t}+\beta_{2} \text { Investment }_{i t}+\beta_{3} \text { Public aid }_{i t}+\beta_{4} \text { Risk }_{\text {capital }}+\beta_{5} \text { Farm size }_{i t} \\
& +\beta_{6} \text { Dummy }_{i t}+\xi
\end{aligned}
$$

where $y$ is the dependent variable and can be thought to be either the income level or the amount of workforce (employment level) as recorded at time $\mathrm{t}+1$ and $\mathrm{t}+2$ and/or $\mathrm{t}+\mathrm{n}$ from the start of the policy intervention; Dummy is the binary variable 0 or 1 to be used in the case of a comparative analysis between different territorial realities; $\xi$ is the error term. The remaining variables are already explained in Table 1 above.

The estimation of such a functional form in log-log terms will give us the possibility of identifying the elasticities characterizing the relationships. However, pending the delivery of more updated income data from the Italian Tax Agency (Agenzia delle entrate), some observations on the main features characterizing the firms participating to the first public call of Measure 121 only are now developed. With regard to this, it must be first highlighted how a number of 5 firms have been eliminated from the database to avoid dangerous outliers rather than having interesting extremes. As a result, the number of firms subject of analysis becomes 1,314 out of 1,321 .

The result of the descriptive analysis is reported in Table 2 below. As it can be observed from the values of the standard deviation, the information considered in the database is characterized by a high level of variability. This tells us that it can adequately be made the subject of econometric investigation. Furthermore, it can be observed how the mean value 
of the firms' income is equal to $€ 45,994$, the size is about 42.24 ha. and the workforce is about 6 . Broadly speaking, this means that we are dealing with firms basically characterized by a very modest dimension. Additionally, it can be noted that the total investment amount is also modest, this being equal to about $€ 160,471$ as an average. As a result, even the risk capital and the public aid quotas are quite small since their mean values are respectively equal to about $€ 88,000$ and $€ 72,500$ as an average.

Table 2: Results of the descriptive statistics analysis

\begin{tabular}{|l|c|c|c|c|}
\hline \multicolumn{1}{|c|}{ Variable } & Observations & Mean & St. Deviation & Skeweness \\
\hline Income & 1312 & 45994.26 & 79818.32 & 0.12 \\
\hline Public aid & 1312 & 72495.97 & $112446 \mathrm{E} 5$ & 5.61 \\
\hline Risk capital & 1312 & 87975.24 & 134170.36 & 5.18 \\
\hline Investment & 1312 & 160471.22 & $239661 \mathrm{E} 5$ & 5.11 \\
\hline Farm size & 1312 & 42.24 & 58.27 & 5.04 \\
\hline Work force & 1312 & 5.78 & 9.50 & 3.88 \\
\hline
\end{tabular}

Source: own elaboration on data from the "Measure 121" database of the Puglia Region

The analysis specifically based on the consideration of the data referred to the two variables represented by income and the size of firms (this intended in terms of workforce) highlights the existence of a high concentration when they are both characterized by law values. The scatter plot here clearly shows such situation.

Figure 2: The relationship between income and workforce

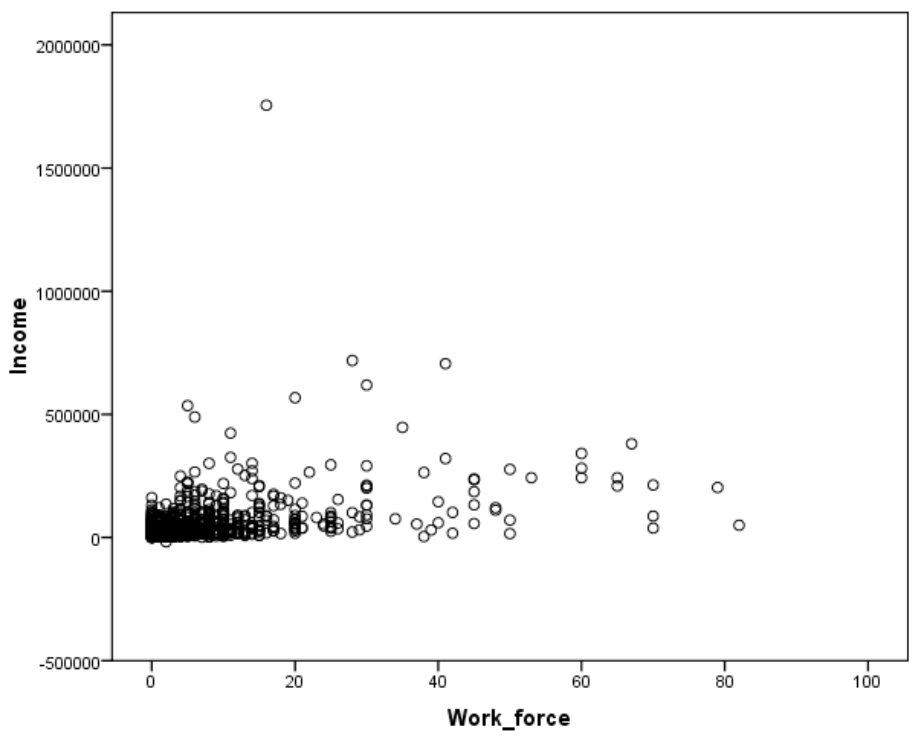

Source: own elaboration on data from the "Measure 121" database of the Puglia Region 
Even the relationship between income and the physical size of farms (in hectares) shows a very high concentration of farms in correspondence of their low levels (see Figure 3).

Figure 3: The relationship between income and farm physical dimension (ha.)

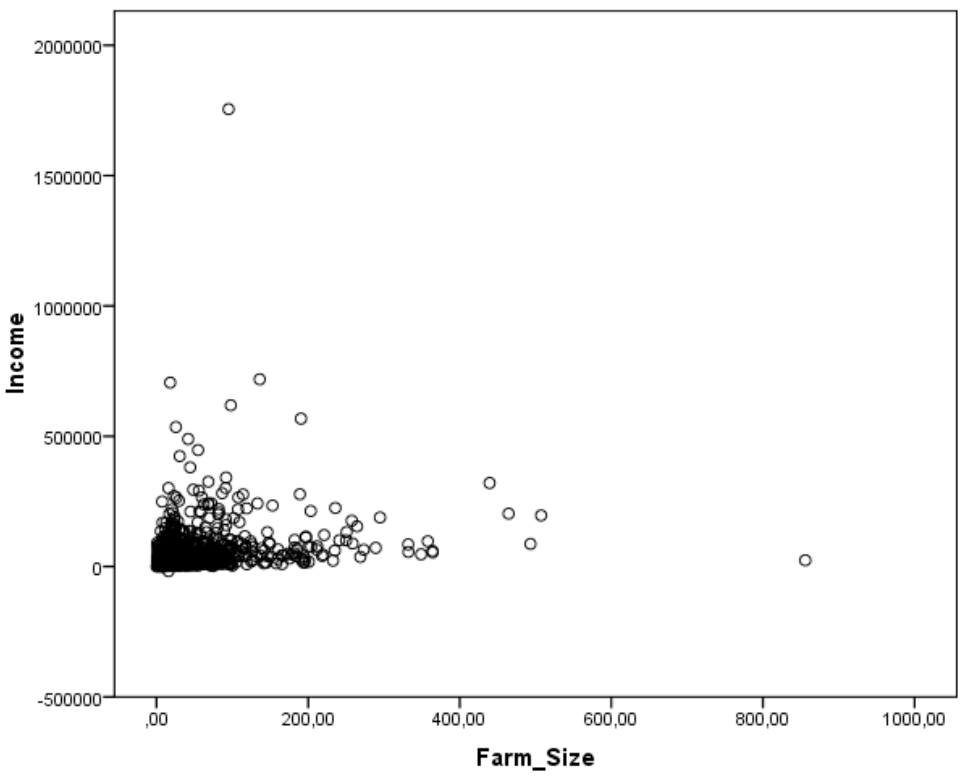

Source: own elaboration on data from the "Measure 121" database of the Puglia Region These two figures would prove that the objectives pursued through the implementation of the policy intervention associated with the Measure 121 are consistent with the main need of the agricultural sector in Puglia. It is generally thought, in fact, that its firms need to go through a significant reorganization process to ensure a modernization of the sector and better capacity for generating higher income and employment levels. As it has already been anticipated, whether this result has really been achieved and with what magnitude is something which should be verified through follow-up analysis based on the reflection developed above.

\section{Conclusions}

The ex-post evaluation of the implementation of public policies represents an issue of general interest. More specifically, an interesting scientific and political debate nowadays exists in relation to the observation of whether the European expenditure for rural development produces positive results. The review of the literature on the issue of policy evaluation, which has been reported in the first section, shows a variety of tools which can be used for empirical analysis. Among these, the Propensity Score Matching is one of the most implemented, although it is characterized by the existence of some limits. After having presented a possible and different framework of analysis to run a policy evaluation task from an econometric view, in this work, the authors have introduced and discussed the main aspects 
associated with a database built by the Management Authority of the Rural Development Plan of the Puglia Region in relation to the Axes I of Measure 121 of its rural development policy the authors would like to evaluate. With specific regard to this, those aspects have been highlighted which do not make this database suitable to appropriate investigations aimed at econometrically analyzing the impact generated by this type of policy. This is especially due to the fact that the Management Authority does not run any ex-post monitoring activity as a follow-up of the implementation of the considered policy. As a result, the lack of information on the income end employment levels characterizing the firms (which have received financial support) after a certain time from the start of the program does not help to carry out ex-post analysis aimed at understanding the impact derived from the investment implementation. As it has been argued, this gap of information can be covered by recurring to other statistics, managed by other national institutions (Agenzia delle entrate), which can help to integrate the regional database with the information on income and employment levels firms have declared in the years after their admission to the development program of the Measure 121. This more complete set of statistical information can allow the running of empirical investigations to understand how the public spending supplied within the framework of the Measure in question impacts the agricultural system in the Puglia Region.

\section{References}

Adelman, I. (1984). Beyond Export-Led Growth. World Development, 12(9): 937-949.

Bradley, D., Dwyer, J., and Hill, B. (2010). The Evaluation of Rural Development Policy in the EU. Eurochoices Article, 9(1): 15-20.

Council Regulation (EC) No. 1698. (2005). Support for Rural Development by the European Agricultural Fund for Rural Development (EAFRD). Official Journal of the European Union. Retrieved September 20, 2005 from http://eur-lex.europa.eu/legal-content/EN/TXT/HTML/?uri $=$ CELEX:32005R1698\&from $=$ en.

Esposti, R., and Sotte, F. (2013). Evaluating the Effectiveness of Agricultural and Rural Policies: An Introduction. European Review of Agricultural Economics, 40(4): 535-539.

European Commission. (2006). Common Monitoring and Evaluation Framework. Agriculture and Rural Development. Retrieved September, 2006 from http://ec.europa.eu/agriculture/rurdev/eval/ index_en.htm.

European Court of Auditors. (2013). Can the Commission and Member States Show that the EU Budget Allocated to the Rural Development Policy Is Well Spent? Special Report No. 12. Retrieved from http://www.eca.europa.eu/Lists/ECADocuments/SR13_12/SR13_12_EN.pdf.

Gélineau, F., Bédard, P.O., and Ouimet, M. (2012). Statistical Simulation and Counterfactual Analysis in Social Sciences. Tutorials in Quantitative Methods for Psychology, 8(2): 96-107.

Haggblade, S., Hazell, P., and Reardon, T. (2007). Transforming the Rural Nonfarm Economy: Opportunities and Threats in the Developing World. International Food Policy Research Institute. Retrieved from http://www.ifpri.org/sites/default/files/publications/transforming_the_rural_nonfarm_economy_opportunities_and_threats_in_the_developing_world.pdf.

Hazell, P., and Haggblade, S. (1991). Rural-Urban Growth Linkages in India. Indian Journal of Agricultural Economics, 46(4): 515-529.

Hirshman, A.O. (1961). The Strategy of Economic Development. The Canadian Journal of Economics and Political Science, 27(1): 110-112.

Hodge, I., and Midmore, P. (2008). Models of Rural Development and Approaches to Analysis Evaluation and Decision-Making. Economié Rurale, 5(307): 23-38.

Imbens, G. W., and Wooldridge, J. M. (2009). Recent Developments in the Econometrics of Program Evaluation. Journal of Economic Literature, 47(1): 5-86.

Johnston, B.F., and Mellor, J. W. (1961). The Role of Agriculture in Economic Development. American Economic Review, 51(4): 566-593. 
Khandker, S. R., Koolwal, G. B., and Samad, H. A. (2010). Handbook on Impact Evaluation. Quantitative Methods and Practices. Washington: World Bank.

Kuznets, S. (1964). Economic Growth and the Contribution of Agriculture: Notes for Measurement. In C. Eicher and L. Witt (eds.), Agriculture in Economic Development. New York: McGraw-Hill.

Lankoski, J., and Ollikainen, M. (2013). Counterfactual Approach for Assessing Agri-environmental Policy: The Case of the Finnish Water Protection Policy. Review of Agricultural and Environmental Studies, 94(2): 165-193.

Lukesch, R., and Schuh, B. (2010). Approaches for Assessing the Impacts of the Rural Development Programmes in the Context of Multiple Intervening Factors. European Evaluation Network for Rural Development. Retrieved March, 2010 from http://enrd.ec.europa.eu/en/networks-and-networking/nrn-self-assessment-tool-kit/looking-beyond-nrn-self-assessment.

Mellor, J.W. (2000). Faster More Equitable Growth: The Relation between Growth in Agriculture and Poverty Reduction. Consulting Assistance on Economic Reform II. Discussion Paper No. 70. Massachusetts: Harvard Institute for International Development.

Merlo, G. (2014). La programmazione sociale: principi, metodi e strumenti. Rome: Carocci Faber.

Ottaviani, L., and Lafiandra, S. (2014). Report sull'avanzamento del bilancio comunitario e della spesa pubblica. Rete Rurale Nazionale. Retrieved February 11, 2014 from http://www.reterurale.it/flex/ $\mathrm{cm} /$ pages/ServeBLOB.php/L/IT/IDPagina/13506.

Ravallion, M. (2008). Evaluating Anti-Poverty Programs. In T. P. Schultz and J. Strauss (eds.), Handbook of Development Economics (59). Washington: World Bank.

Rosenstein-Rodan, P. (1943). How Important to India’s Poor is the Sectorial Composition of Economic Growth. World Bank Economic Review, 53(210/2011): 202-211.

Russo, C. (2014). Ex-post Evaluation of the Impact of Rural Development Policy Using Farm-level Data. An Example from the 2000-2006 Program in the Lazio Region. Contributed Paper at the 51th SIDEA Conference: La PAC 2014-2020: scenari per i sistemi agroalimentari e rurali europei. Retrieved September 18-20, 2014 from http://www.sidea.org/Benevento_14.html.

Russo, C., and Sabbatini, M. (2005). Analisi esplorativa delle differenziazioni strategiche nelle aziende agricole. Rivista Economia Agraria, (4).

Shaxon, L. (2011). Evidence-based Agricultural and Rural Policy Development - A View from the UK on Linking Research and Policy. Contributed Paper at the 122nd Seminar of the EAAE, EvidenceBased Agricultural and Rural Policy Making: Methodological and Empirical Challenges of Policy Evaluation. Retrieved February 17-18, 2011 from http://eaae-seminar.univpm.it.

Weiss, C. (1998). Evaluation: Methods for Studying Programs and Policies. New York: Prentice Hall.

Weiss, C. H. (2000). The Experimenting Society in a Political World. In L. Bickman (ed.), Validity and Social Experimentation: Donald Campbell's Legacy (283-302). Thousand Oaks, CA and London: Sage.

White, H. (2006). Impact Evaluation - The Experience of the Independent Evaluation Group of the World Bank. Independent Evaluation Group. Washington: World Bank.

White, H. (2009). Theory-Based Impact Evaluation: Principles and Practice. Journal of Development Effectiveness, 1(3): 271-284. 


\title{
KAIMO PLĖTROS POLITIKOS POVEIKIO APULIJOS REGIONE İVERTINIMO TRŪKUMAI: I KRYPTIES 121 PRIEMONĖS ATVEJIS
}

\author{
Pasquale PAZIENZA \\ Donatello CARUSO \\ Vincenzo VECCHIONE \\ Fogia universitetas, Italija
}

Santrauka. Šiame darbe analizuojame kai kuriuos specifinius Apulijos regiono (Pietų Italija) kaimo pletros plano 2007-2013 metams aspektus ir išryškiname trūkumus, charakterizuojančius analizès sistemos kūrimo galimybę, siekiant suprasti, kaip ji iš tikrųjų paveikia regioninę žemès ūkio sistemą. Tiksliau, remiantis konkrečia kaimo plètros programos priemone (I krypties 121 priemone), mūsų tikslas yra patikrinti, ar iš ịgvendinamos investicinès veiklos iš tiesų galima tikètis teigiamų rezultatų ir teigti, kad kaimo plètrai skirtas ES biudžetas yra tinkamai panaudotas. Siekdami šio tikslo rinkome visą prieinamą Apulijos regiono valdžios institucijų informaciją. Peržiūrèję surinktus duomenis pastebejome egzistuojančius apribojimus, kylančius iš to, kaip regioninè valdžia valdo duomenų rinkimą. Pagrindinis šio darbo tikslas yra pateikti politikos vertinimo analizès struktūrą ir aptarti, kas turètų būti mūsų empirinių tyrimų objektas.

Reikšminiai žodžiai: vietovių ir kaimo plètra, investicijų ịvertinimas, regioninès politikos ịvertinimas, regioninès plètros planavimo priemonès. 